\title{
CLONAL DIVERSITY IN TARAXACUM OFFICINALE (COMPOSITAE), AN APOMICT
}

\author{
JENNIFER C. LYMAN AND NORMAN C. ELLSTRAND \\ Department of Botany and Plant Sciences, University of California, Riverside, \\ California 92521, USA
}

Received 9.viii.83

\section{SUMMARY}

Allozyme analysis, morphological characters, and histocompatibility relationships have revealed unexpected amounts of clonal diversity within and among populations of unisexual animals. Plant studies, likewise, have shown that genetic diversity exists in populations of plants that have restricted recombination. However, no work has been done which investigates the extent of genotypic diversity within and among populations of an obligate apomict.

This study surveyed 22 North American populations of Taraxacum officinale, an obligate gametophytic apomict. Over 20 individuals from each population were assayed electrophoretically for three enzyme systems representing five different migration zones. Seed colour was used to determine seven phenological classes that, when combined with the allozyme morphs, resulted in 47 discernible clones among 518 individuals sampled. Chromosome analysis revealed the ploidy level to be triploid in all cases.

The number of clones per population ranged from $1-13$, with a mean of $5 \cdot 0$. Sixty-six per cent of the clones were restricted to single populations, and the mean number of populations containing a particular clone is $2 \cdot 1$. One widespread clone was found in all but three of the populations. Diversity values, expressed as clones per individual, indicate that $T$. officinale proved to be more genotypically diverse than other clonal plants previously studied. Spearman's Rank Correlation test failed to show a correlation of diversity with latitude or elevation.

\section{INTRODUCTION}

Investigation of the population genetic structure of clonal organisms has focused mainly on asexual animals. Studies using gel electrophoresis, morphological characters and/or histocompatibility relationships have exposed unexpectedly high levels of genetic variation within and among populations of several asexual species, including unisexual weevils (Suomalainen et al., 1977), sea anemones (Black and Johnson, 1979), fishes (Schultz, 1977), lizards (Parker and Selander, 1976), and annelids (Christensen et al., 1978; Jaenike et al., 1980).

Despite the fact that asexuality is much more common in the plant kingdom than the animal (e.g., Fryxell, 1957), little work has been devoted to the examination of genetic diversity both within and among populations of asexual plant species. Clonal plant species should have low levels of within-population polymorphism but high interpopulation differentiation (e.g., Baker, 1959; Levin and Kerster, 1971). The ideal test for this hypothesis is the examination of the population structure of an obligate apomict. The few plant studies of clonal diversity have tested only one or a few populations of a particular species (Harberd, 1961, 1967; Solbrig and Simpson, 1974; Wu et al., 1975; Hancock and Wilson, 1976; Steiner 
and Levin, 1977) or concentrated on interpopulational differences (Babcock and Stebbins, 1938; Gustafsson, 1946; Grant and Grant, 1956; Solbrig, 1971). The only within- and between-populational surveys of genetic diversity in clonal plants are for species which are not strictly asexual but have some rare opportunities for recombination (Levin and Crepet, 1973; Levin, 1975; Ellstrand and Levin, 1980, 1982).

The measurement of genetic diversity in asexual plant species can be accomplished with a variety of techniques. Solbrig and Simpson (1974), for example, used isozyme analysis to demonstrate that the three populations of Taraxacum officinale which they studied were multiclonal. Hancock and Wilson (1976) also found electrophoretically discernible clones in populations of Erigeron annuus. Steiner and Levin (1977) used a combination of techniques-including electrophoresis, incompatibility alleles, and chromosome studies-and showed that the combination exposed more genotypic diversity than by any single technique. However, no study has yet combined the investigation of population structure in a highly asexual species using a combination of assay techniques with the analysis of a large number of populations that cover a major portion of the species' range.

The object of this study, then, is to survey clonal diversity within and among a large number of populations of an obligate apomictic plant using morphological characters, chromosome counts, and electrophoresis, and to compare this diversity with that exhibited in populations of other plant species which display either highly restricted recombination or some asexual form of reproduction.

The species studied is Taraxacum officinale Wiggers, a triploid gametophytic apomict, $X=8,2 N=24$ (Munz, 1968; Grant, 1981). This species is presumed to be naturalized in the United States and has successfully invaded waste places, roadsides, fields, and pastures (Solbrig, 1971). A perennial species, it is also capable of germinating, forming rosettes, flowering, and setting seed in a single year. Reports of sexuality within populations of this species have been made in Europe (Valentine and Richards, 1967) involving the mating of triploid and diploid plants. No sexuality has yet been reported for the United States populations of $T$. officinale, despite the fact that abundant pollen is often produced by the plants.

The taxonomy of the genus Taraxacum is controversial. While nearly 2000 microspecies have been described (Richards, 1972), Grant (1981) and Gustafsson (1946) contend that apomictic Taraxacum belong to relatively few large agamic complexes. In the present study, the classification of $T$. officinale is taken in the broad sense and relies on those characters easily discernible in the field.

\section{MATERIALS AND MethodS}

One ripe seed head was collected from each of 30 randomly selected plants from each of 22 populations across the United States during June and July 1980 (fig. 1). For this study, collections of seed material were limited to plants within c. 1 ha. The heads were considered to be ripe when they fully opened and all seeds exposed to the wind. The plants sampled were well separated spatially to insure that rosettes were not attached to the same tap root (Naylor, 1941). All collections were made from lawns, 


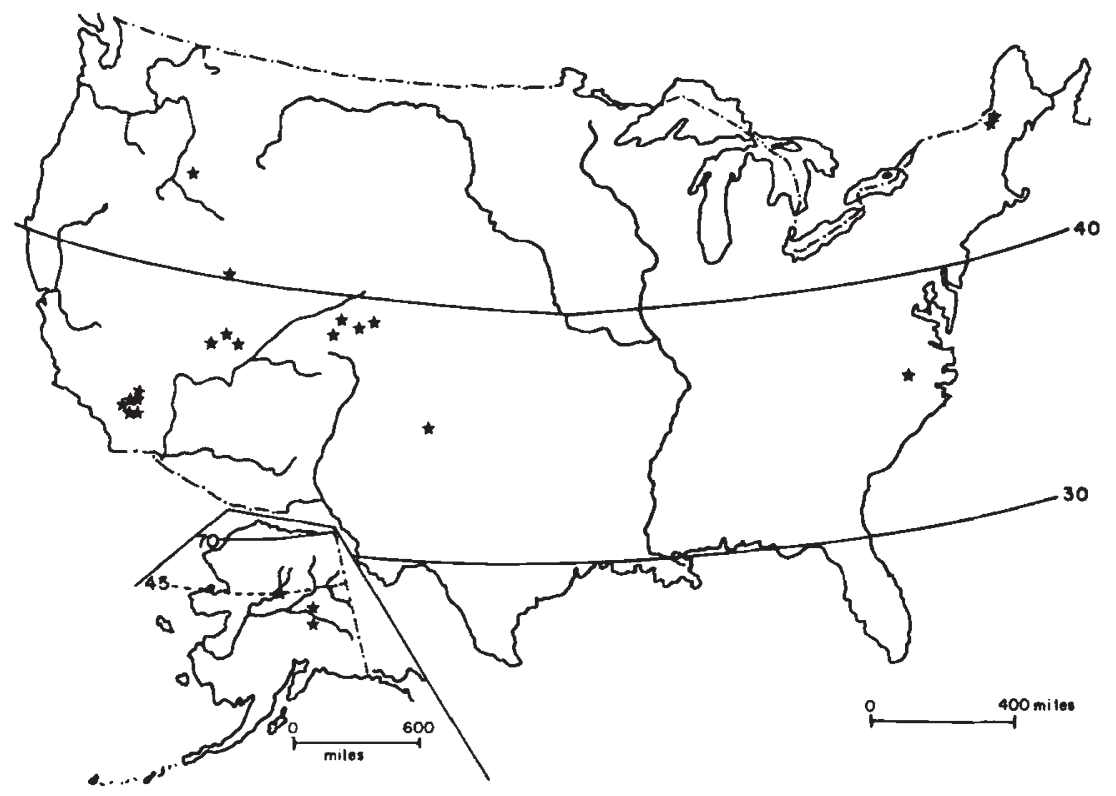

FIG, 1. Sketch map of the collection sites of Taraxacum officinale.

roadsides, pastures, or other disturbed sites. Seeds from each head were germinated in the glasshouse in four-inch styrofoam cups and later transferred to clay pots in the lathhouse. Germination occurred readily within 3-7 days, and one seedling per source plant was allowed to grow to maturity for electrophoretic analysis. Plants from other seeds on each head were used for morphological study and chromosome count.

\section{(i) Electrophoretic analysis}

Electrophoretic variants of three different enzyme systems (phosphoglucomutase, PGM; phosphoglucoisomerase, PGI; and alcohol dehydrogenase, $\mathrm{ADH}$ ) were assayed according to methods described by Heywood (1980). Isozyme patterns in related species (Roose and Gottlieb, 1976) suggest that five gene loci are involved. Unopened flower buds from a total of 20 plants per wild population of $T$. officinale were used. The bud tissue was homogenised in two drops of extraction buffer, $0.01 \mathrm{MDTT}$ buffered with $0 \cdot 1 \mathrm{M}$ Tris- $\mathrm{HCl}, p \mathrm{H} \mathrm{7 \cdot 0}$. The homogenates were applied to paper wicks and electrophoresis was conducted in 12 per cent electrostarch gels for 4 hours at 50 milliamps. The Tris-EDTA-borate continuous buffer system was used (Heywood, 1980). Ice packs were placed on the gels during the run to prevent overheating. In order to determine whether patterns from different populations were electrophoretically equivalent, internal standards were run on the same gel.

\section{(ii) Chromosome counts}

Chromosome numbers were counted in two individuals per population using mitotic cells in root tips germinated on moist filter paper in petri 
dishes. Four- to six-day-old root tips were placed in vials in 0.2 per cent colchicine solution for 2 hours and then fixed in $1: 3$ aceto-alcohol (Richards, 1972). The root tips were hydrolysed in $0.1 \mathrm{~N} \mathrm{HCl}$ for 11 minutes at $60^{\circ} \mathrm{C}$ and then stained in Feulgen solution for at least 1 hour before the squashes were prepared (Löve and Löve, 1975). Two-mm lengths of the root tip were squashed on a microscope slide in 1 per cent aceto-propionic acid before viewing under the microscope. A minimum of three metaphase plates from which counts could be made were examined.

\section{(iii) Seed characters}

Seed length, the number of longitudinal grooves on the seed surface, the distance of seed colour penetration onto the beak or rostrum, the percentage rugosity on the seed surface, and the colour of the seed were examined for morphological variation among clones. Measurements were made on one seed per head and 20 heads per population. Further examination of one seed head per population showed that colour was uniform within a capitulum. Progeny analysis demonstrated that plants breed true for seed coat colour.

\section{RESUlts}

Genotypic variation is present within and among the 22 populations of $T$. officinale investigated. The enzyme systems surveyed by electrophoresis uncovered 21 different allozyme phenotypes among the 518 individuals assayed. Morphological analysis of seed characters revealed that seed colour was the single character which sorted into discrete classes. The other characters showed continuous variation and were discarded. Seven colour classes were apparent from the survey of 20 heads per population. The root tip squashes of two individuals per population revealed the ploidy level to be triploid in all of the populations. Therefore, additional diversity could not be measured by chromosomal variation.

Each technique, electrophoresis and morphological analysis, revealed variation that the other did not. By allozyme analysis alone, for example, nine phenotypes were found in the Idyllwild, California population while only six morphs were revealed by seed colour alone (table 1). Using both allozymes and seed colour, a total of 13 morphs occurs in that population. In the Caspian Lake, Vermont population, on the other hand, three clones were found using morphology alone and two through allozyme analysis. Because these involved different individuals, a total of five morphs compose this population.

When the allozyme patterns were combined with the seven colour classes, then, a total of 47 different clonal types result for all the populations. The total number of discernible clones for each population is presented in table 1 . The number of clones ranges from one to 13 per population, with a mean value of $5 \cdot 0$. The distribution of clones per population is highly skewed (fig. 2). Most populations have few clones while there are a large number of clones in only a few of the populations. Two populations are apparently uniclonal.

The distribution of clones over populations is L-shaped (fig. $3 ; \bar{x}=2 \cdot 1$ ). Most clones are restricted to one or a few populations; very few clones are 
TABLE 1

Taraxacum populations: allozyme and seed colour phenotypes and total genotypes per population

\begin{tabular}{lrcccc}
\hline \multicolumn{1}{c}{ Location } & Altitude & $\begin{array}{c}\text { Allozyme } \\
\text { phenotype }\end{array}$ & $\begin{array}{c}\text { Seed } \\
\text { colour }\end{array}$ & $\begin{array}{c}\text { Total } \\
\text { morphs }\end{array}$ & $\begin{array}{c}\text { Sample } \\
\text { size }\end{array}$ \\
\hline Idyllwild, CA & 5500 & 9 & 6 & 13 & 27 \\
San Jacinto, CA & 1500 & 2 & 3 & 5 & 23 \\
Beaumont, CA & 2300 & 2 & 4 & 3 & 25 \\
Hemet, CA & 1700 & 2 & 2 & 6 & 28 \\
Riverside, CA 1 & 1200 & 1 & 1 & 1 & 20 \\
Riverside, CA 2 & 1200 & 2 & 1 & 2 & 29 \\
Salt Lake, UT & 4300 & 1 & 3 & 3 & 20 \\
Boulder, UT & 9000 & 3 & 2 & 5 & 25 \\
Cedar Breaks, UT & 10,000 & 2 & 2 & 2 & 22 \\
Red Cliff, CO & 9600 & 3 & 3 & 4 & 25 \\
Loveland, CO & 11,990 & 3 & 4 & 6 & 22 \\
Gothic, CO & 9500 & 3 & 5 & 11 & 23 \\
Gennessee, CO & 6000 & 4 & 4 & 7 & 29 \\
Melba, ID & 1300 & 3 & 1 & 3 & 22 \\
Caspian, VT & 1800 & 2 & 3 & 5 & 25 \\
Elmore, VT & 1600 & 5 & 3 & 8 & 22 \\
Amarillo, TX & 3000 & 3 & 3 & 5 & 25 \\
Durham, NC & 300 & 7 & 3 & 8 & 23 \\
Fairbanks, AK & 432 & 1 & 1 & 1 & 20 \\
Manley, AK & 400 & 2 & 1 & 3 & 23 \\
Harding Lake, AK & 600 & 2 & 3 & 4 & 20 \\
Bryce, UT & 9000 & 4 & 3 & 6 & 20 \\
\hline
\end{tabular}

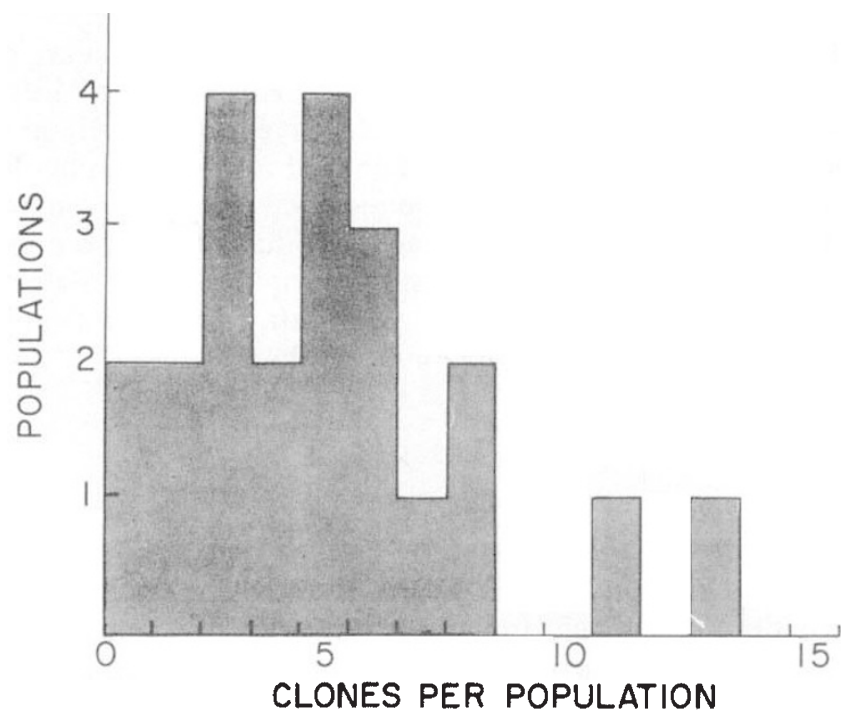

FIG. 2. Distribution of distinguishable clones over populations. 


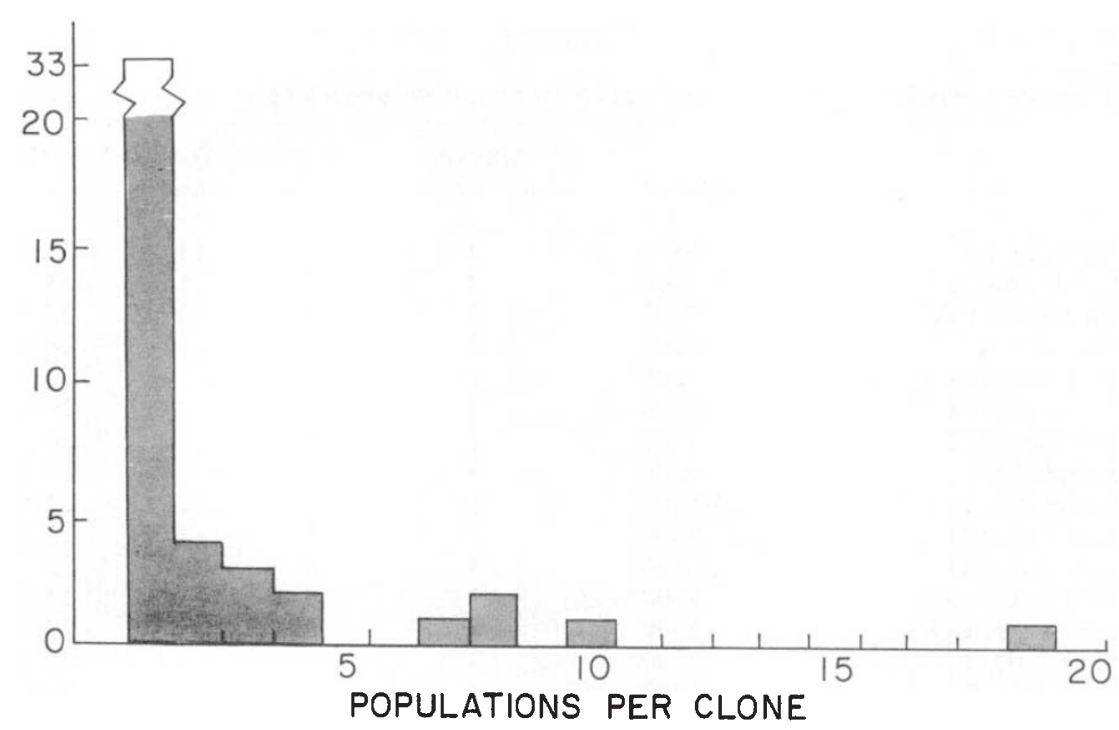

FIG. 3. Distribution of populations over distinguishable clones.

widely distributed. Fifty-five per cent of the populations contain a unique phenotype. Sixty-six per cent of the clones are restricted to single populations. On the other hand, some clones are widespread; one is present in 19 populations which range from Vermont to California to Alaska, and absent in only three.

Pielou's corrected version of the Gini Index was used to measure clonal diversity in each population (see Ellstrand and Levin, 1982). This index, $D$, can be as little as 0 (minimum diversity for a uniform sample) or as large as 1 (a completely heterogenous sample). The values for the $T$. officinale populations range from 0.00 to $0.89(\bar{x}=0.50)$. Evenness values, which reflect how evenly the individuals within a population are distributed among the clones, were also calculated (cf., Ellstrand and Levin, 1982). These values $(0 \cdot 00-1 \cdot 00, \bar{x}=0 \cdot 49)$ are displayed graphically in fig. 4 . The striking bimodal nature of the distribution discriminates among those populations with a dominant clone (low evenness values) and those in which the clones are equitably distributed among individuals (high evenness values).

Spearman's Rank Correlation test was applied to the data to test for correlation of diversity with latitude or elevation. No significant trends in genotypic diversity were detectable along either gradient.

\section{Discussion}

This study reveals considerable genotypic diversity both within and among populations of a clonal species, $T$. officinale. The data concur with findings in clonal animals and with other clonal plant species. A total of 47 clones were identified in this analysis, more than in any other plant species studied except for Oenothera laciniata (table 2). The differences apparent in the total diversity values (D) may be partly a function of the varying sample sizes in the studies. If the clonal diversity is measured on a perindividual-sampled basis for each species, then $T$. officinale has 0.091 


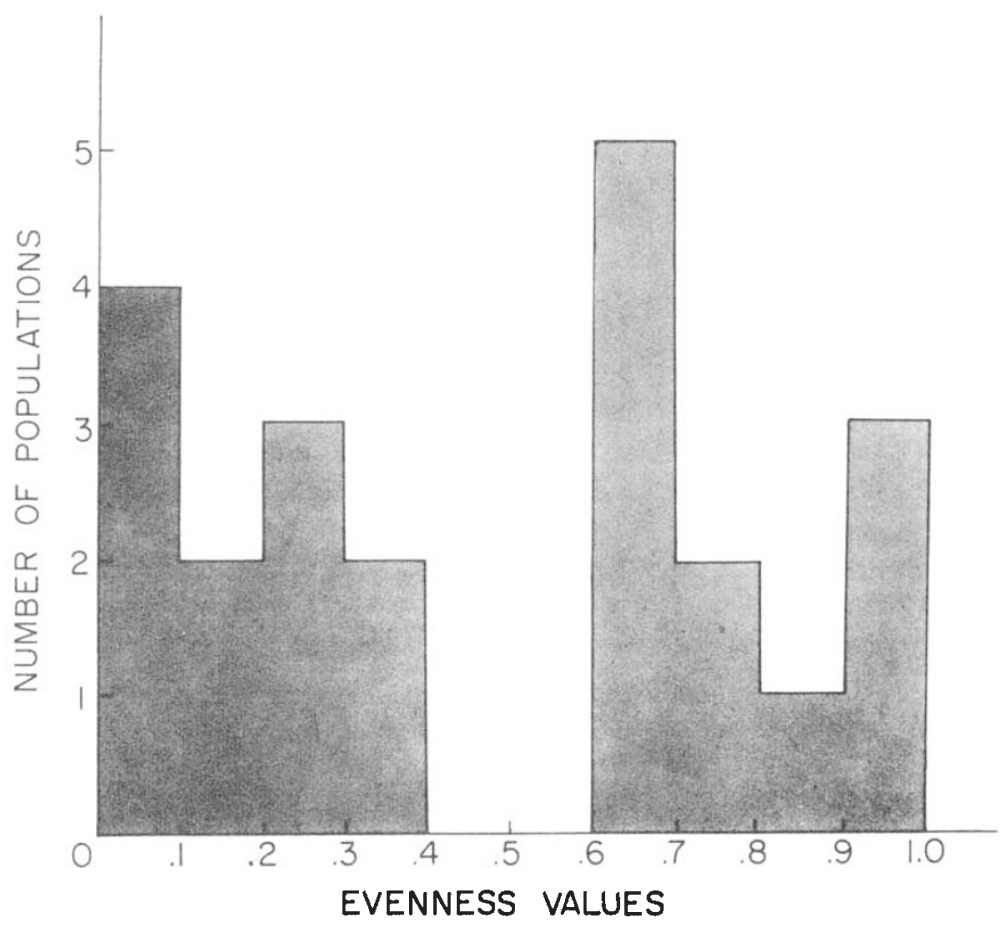

FIG. 4. Distribution of clonal evenness values over populations.

TABLE 2

Genotypic diversity among populations of clonal plant species

\begin{tabular}{lccc}
\hline \multicolumn{1}{c}{ Taxon } & Pops./N & Clones & Clones/Ind. \\
\hline E. annuus & $3 / 300$ & 17 & 0.056 \\
T. officinale & $3 / 284$ & 4 & 0.014 \\
T. officinale & $22 / 518$ & 47 & 0.091 \\
L. lucidulum & $16 / 242$ & 19 & 0.078 \\
O. biennis & $3 / 75$ & 4 & 0.053 \\
O. biennis & $44 / 2200$ & 46 & 0.021 \\
O. laciniata & $60 / 2400$ & 108 & 0.045 \\
\hline
\end{tabular}

${ }^{1}$ References in text.

genotypes per individual, a value higher than all other species. $O$. laciniata, while containing the highest number of total genotypes, has only 0.045 genotypes per individual.

In light of this relatively high genetic diversity, it is useful to compare these results to a more restricted study with $T$. officinale that involves three populations in different microhabitats (Solbrig and Simpson, 1974), which involved the same number of allozyme markers as this study. The populations in this genecological study were separated by a distance of less than $500 \mathrm{~m}$, which allowed for intersite seed flow (Sheldon and Burrows, 1973), 
but had undergone radically different disturbance regimes (Solbrig and Simpson, 1974). The genotypes per individual values in our investigation are nearly an order of magnitude larger than in the geographically restricted study, 0.097 versus 0.014 , as shown by table 2 . But even our broad study, because of limits to sampling, has probably uncovered only a fraction of the total clonal diversity in $T$. officinale. Furthermore, allozyme analysis using additional enzyme systems would be likely to reveal additional clones.

Our study has shown a localised distribution of clones over the populations. Most genotypes (66 per cent; 33 of 47 ) are restricted to one population. But one morph occurred in 19 populations. The populations that lack this particular clone are widely separated geographically, in Alaska and California. Another way to examine the distribution of clones is to compare the number of populations per clone for each species in table 2 . The average number of populations per clone for $T$. officinale is $2 \cdot 1$. The only other study undertaken for a clonal plant species by sampling over a major part of the range involved $O$. laciniata, which has $5 \cdot 2$ populations per clone. In the latter case, although many clones are restricted to a single population, more are widely distributed than those of $T$. officinale. Another Oenothera species, $O$. biennis, on the other hand, was sampled extensively from within a single state (Levin, 1975) and shows an average of 1.5 populations per genotype, a value closer to that of $T$. officinale. The contrasting trends for Oenothera have been discussed elsewhere (Ellstrand and Levin, 1982). The rationale that explains the trends in Oenothera species is that $O$. laciniata arose from polyphyletic origins (Ellstrand and Levin, 1982).

A similar rationale could explain diversity in $T$. officinale; namely, multiple introductions from Eurasia. Explanations for the existence of numerous clones of the species in Eurasia rely on evidence from Sorensen and Gudjonsson (1946) and Valentine and Richards (1967) who have shown that residual sexuality and/or a high somatic mutation rate are the likely causes of this variability in European populations. In the United States, no sexual individuals of this species have been discovered. The fact that we have found only triploidy in the plants sampled here appears to confirm that sexuality is indeed very rare or absent in North American T. officinale.

Adaptation to microhabitat may permit clonal coexistence (Vrijenhoek, 1978). The experimental studies of Solbrig and Simpson (1974) demonstrated that disturbance may determine genotype dominance in $T$. officinale. Field studies by Ford (1981) have shown that local co-existence of dandelion clones may be due to the existence of a range of "pre-adapted clones" that are maintained in proportions relating to the distribution of adequate microsites.

The numerous clones reported here are probably the result of multiple introductions of genotypes into the United States from Europe. Patterns of distribution may be a result of the time that has passed since introduction (Harberd, 1961) or the presence of suitable microhabitats or both. Still uninvestigated is somatic mutation rate in $T$. officinale within the United States and its potential role in the evolution of genotypes since the first introduction of this species. Only extensive study of the dynamics of multiclonal populations over time using experimental demography to follow the particular genotypes can test these hypotheses regarding the ecological coexistence of clones. These studies are now under way. 


\section{REFERENCES}

BABCOCK, E. B. AND STEbBins, G. L. 1938. The American species of Crepis. Their interrelationships and distribution as affected by polyploidy and apomixis. Carnegie Inst. Wash. Publ. No. 504.

BAKER, H. G. 1959. Reproductive methods as factors in speciation in flowering plants. Cold Spring Harbor Symp. Quant. Biol., 24, 177-191.

BLACK, R. AND JOHNSON, M. S. 1979. Asexual vivipary and population genetics of Actinia tenebrosa. Marine Biol., 53, 27-31.

CHRISTENSEN, B., BERG, M. AND JELNES, J. 1978. A comparative study on enzyme polymorphism in sympatric diploid and triploid forms of Lumbricillus lineatus (Enchytraeidae, Oligochaeta). Hereditas, 44, 169-176.

CHRISTENSEN, B., BERG, M. AND JELNES, J. 1980. Recombination system and population structure in Oenothera. Evolution, 34, 923-933.

CHRISTENSEN, B., BERG, M. AND JELNES, J. 1982. Genotypic diversity in Oenothera laciniata (Onagraceae), a permanent translocation heterozygote. Evolution, 36(1), 63-69.

ELLSTRAND, N. C. AND LEVIN, D. A. 1980. Recombination system and population structure in Oenothera. Evolution, 34, 923-933.

ELLSTRAND, N. C. AND LEVIN, D. A. 1982. Genotypic diversity in Oenothera laciniata (Onagraceae), a permanent translocation heterozygote. Evolution, 36, 63-69.

FORD, H. 1981. Competitive relationships amongst apomictic dandelions. Biol. J. Linn. Soc., $15,355-368$.

FRYXELL, P. A. 1957. Mode of reproduction in higher plants. Bot. Rev., 23, 135-233.

GRANT, v. 1981. Plant Speciation, 2nd ed., Columbia Univ. Press, New York.

GRANT, V. AND GRANT, K. 1956. Genetic and taxonomic studies in Gilia. VIII. The Cobwebby Gilias. Aliso, 3, 203-287.

GUSTAfSSON, A. 1946 Apomixis in Higher Plants. Lund, C. W. K. Glerrup.

HANCOCK, J. F., JR. AND WILSON, R. E. 1976. Biotype selection in Erigeron annuus during old field succession. Bull. Torrey Bot. Club, 103, 122-125.

HARBERD, D. J. 1961. Observations on population structure and longevity of Fustuca rubra L. New Phytol., 60, 184-206.

HARBERD, D. J. 1967. Observation on natural clones in Holcus mollis. New Phytol., 66, 401-408.

HEYWOOD, J. S. 1980. Genetic correlates of edaphic differentiation and endemism in Gaillardia. Ph.D. dissertation, Univ, of Texas, Austin.

JAENIKE, J., PARKER, E. D., JR. AND SELANDER, R. K. 1980. Clonal niche structure in the parthenogenetic earthworm Octolasian tyrtaeum. Am. Natur., 116, 196-205.

LEVIN, D. A. 1975. Genic heterozygosity and protein polymorphism among local populations of Oenothera biennis. Genetics, 79, 477-491.

LEVIN, D. A. AND CREPET, W. L. 1973. Genetic variation in Lycopodium lucidulum: a phylogenetic relic. Evolution, 27, 622-632.

LEVIN, D. A. AND KERSTER, H. W. 1971. Neighborhood structure in plants under diverse reproductive methods. Am. Natur., 105, 345-354.

Löve, A. AND LövE, D. 1975. Plant Chromosomes. J. Cramer, Vaduz.

MUnZ, P. A. 1968. A California Flora. Univ. Calif. Press, Berkeley.

NAYLOR, E. 1941. The proliferation of dandelions from the roots. Bull. Torrey Bot. Club, 68 , 351-358.

PARKER, E. D. AND SELANDER, R. K. 1976. The organization of genetic diversity in the parthenogenetic lizard Cnemidophorus tessalatus. Genetics, 84, 791-805.

RICHARDS, A. J. 1972. The karyology of some Taraxacum species from alpine regions of Europe. Bot. J. Linn. Soc., 65, 47-59.

ROOSE, M. L. AND GOTTLIEB, L. D. 1976. Genetic and biochemical consequences of polyploidy in Tragopogon. Evolution, 30, 818-830.

SCHULTZ, R. J. 1977. Evolution and ecology of unisexual fishes. Evol. Biol, 10, 277-331.

SHELDON, J. AND BURROWS, F. M. 1973. The dispersal effectiveness of the achene pappus units of selected Compositae in steady winds with convection. New Phytol., 72, 665-675.

SILANDER, J. A. 1979. Microevolution and clone structure in Spartina patens. Science, 203, 658-660.

SOLBRIG, O. T. 1971. The population biology of dandelions. Am. Sci., 59, 686-694.

SOLBRIG, O. T. AND SIMPSON, B. B. 1974. Components of regulation of a population of dandelions in Michigan. J. Ecol., 62, 473-486. 
SOLBRIG, O. T. AND SIMPSON, B. B. 1977. A garden experiment on competition between biotypes of the common dandelion (Taraxacum officinale). J. Ecol., 65, 427-430.

SORENSON, T. AND GUDJONSSON, G. 1946. Spontaneous chromosome aberrants in apomictic Taraxaca. Kong. danske Vid. Seleske Biol. Skrifte, 4, 1-48.

STEINER, E. AND LEVIN, D. A. 1977. Allozyme, SI gene, cytological and morphological polymorphism in a population of Oenothera biennis. Evolution, 31, 127-133.

SUOMALAINEN, E., SAURA, A. AND LOKKI, J. 1977. Evolution of parthenogenetic insects. Evol. Biol., 10, 209-257.

VALENTINE, D. AND RICHARDS, A. J. 1967. Sexuality and apomixis in Taraxacum. Nature, $214,114$.

VRIJENHOEK, R. C. 1978. Coexistence of clones in a heterogeneous environment. Science, 199, 549-552.

WU, LIN, BRADSHAW, A. D. AND THURMAN, D. A. 1975. The potential for evolution of heavy metal tolerance in plants. III. The rapid evolution of copper tolerance in Agrostis stolonifera. Heredity, 32(2), 165-187.

\section{HAVE YOU AN APPLE \| OR \|O? DO YOU ANALYSE DATA? STATSEASE}

STATSEASE is a great deal more than just a series of statistical routines. It is an interactive set of programs that examines your data, and helps you to choose the appropriate statistical tests. Having done so, it carries out the tests automatically, giving the statistics and probabilities with great speed and without further effort. It covers a wide range of tests, both parametric and non-parametric. It displays histograms and scatter-diagrams and automatically transforms your data to logarithms, square roots, angles, or reciprocals. It contains built-in 'tables' of many distributions, including the Normal, Binomial, Poisson, Student's $t, F, r$, and chi-squared.

Among the tests are: $2 \times 2$ chi-squared, Fisher's Exact Test, RXC chi-squared, Haldane's Test for large contingency tables with low expectations, $t$-test for paired and unpaired data, Bailey's $t$-test for data with unequal variances, Mann-Whitney $U$ Test, Bartlett's Test for the homogeneity of variance, one-way analysis of variance (including comparisons between individual groups). Kruskal-Wallis non-parametric analysis of variance, regression and correlation, Spearman's rank correlation, and tests for skewness and kurtosis. There are facilities that allow the addition, removal or correction of data values, printing options, and the ability to store and retrieve data on disk.

STATSEASE was designed for the working scientist, and we believe that it is the best statistical package available. It is also exceptionally useful in teaching statistics.

We decided its price by halving that of the nearest competitor (which does a good deal less). The price is $\mathbf{E} 89.00$, inclusive of VAT, postage and packing.

STATSEASE can be obtained from Prof. B. C. Clarke, Department of Genetics, University Park, Nottingham NG7 2RD, England. Cheques should be made payable to 'The University of Nottingham'. 